\title{
Site Selection for Rainwater Harvesting Structures Using GIS for the Augmentation of Groundwater
}

\section{Elangovan $\mathrm{K}^{1 *}$ and Selva kumar $\mathrm{P}^{2}$}

${ }^{1}$ Associate Professor, Department of Civil Engineering, PSG College of Technology, India ${ }^{2}$ Former ME Infrastructure Engineering student, Department of Civil Engineering, PSG College of Technology, India

*Corresponding author: Elangovan Krishnan, Associate Professor, Department of Civil

Research article

Volume 2 Issue 3

Received Date: April 01, 2018

Published Date: April 20, 2018

DOI: $10.23880 /$ jenr-16000129

Engineering, PSG College of Technology, Coimbatore-641004, India, Email: elangovan2k@hotmail.com

\section{Abstract}

Groundwater is a precious resource and need to be carefully protected since withdrawal rates exceed recharge rates at many places in the world. In order to augment the groundwaterresource, rainwater harvesting is to be adopted. Geographic Information System (GIS) is the tool currently available to handle large volume of spatial data along with attributes. The study area selected is Coimbatore corporation (old) in Tamil Nadu, India. Maps like soil distribution, slope, geology, geomorphology and lineament were classified using Arcview GIS. The Model Builder in the Arc View GIS was used to give Weightage for various layers and select site suitable for recharge structures. Suitable locations for rain water harvesting to augment groundwater were selected for Coimbatore city

Keywords: Coimbatore; Rainwater Harvesting; Geographical Information System; Weighted overlay; Recharge structures

\section{Introduction}

Water is one of the most vital requirements for economic and social development. Indian population is increasing and it demands more and more water for domestic, agricultural and industrial use. Groundwater is the largest reservoir of fresh water in Earth which is essential for life. As global water demands rise and surface water source become further stressed and exploited, human beings are growing increasingly dependent on ground water resources. Surface water resources are inadequate to meet the water requirement due to unequal distribution of precipitation. In order to prevent the depletion of groundwater, artificial recharging of groundwater water is required. Groundwater quality is deteriorated due to depletion of water table beyond the permitted level. This was addressed by Geethaselvarani and Elangovan [1], Arumugam and Elangovan [2], Arumugam Karuppapillai and Elangovan Krishnan [3]. To augment the groundwater level and improve the groundwater quality, site selection for rainwater harvesting structures and suitable areas of groundwater potential zones were studied in detail by DurgaRao and Bhaumik [4], Ghayoumian Mohseni, et al. [5], Abdallah Ben Mammou and Ismail Chenini [6], Gavade, et al. [7], Geetha Selvarani, et al. [8], Geetha 


\section{Journal of Ecology \& Natural Resources}

Selvarani, et al. [9], Samson and Elangovan [10], Maheswaran, et al. [11], GeethaSelvarani, et al. [12] and Selvarani, et al. [13].

\section{Aim and Objectives}

The aim of this study is to produce a groundwater recharge potential map of Coimbatore Corporation (old) using GIS.

The objectives of the study is

1. To demarcate the ground water recharge potential zones using GIS technique.

2. To create a digital database for groundwater development for future.

3. To locate suitable sites for implementing artificial recharge structures.

\section{Study Area}

The old Corporation area of Coimbatore is the study area selected which is situated in the Southern part of the Peninsula at a longitude of $76^{\circ} 54^{\prime} 00^{\prime \prime}$ and $77^{\circ} 04^{\prime} 00^{\prime \prime}$ and latitude of $10^{\circ} 57^{\prime} 30^{\prime \prime}$ and $11^{\circ} 03^{\prime} 30^{\prime \prime}$. The total geographical area of the city is 105.5 sq.km. The city is called as Manchester of South India due to the existence of several cotton mills. Also the city is known for entrepreneurship and several automobile, wet grinder, foundry and pump industries are existing at small, medium and large scale level. Also Coimbatore district is known for its extensive agricultural activity. Coimbatore is a city with average annual rainfall between 600$700 \mathrm{~mm}$. Since the city is in rain shadow region and also the use of deep pumps to extract groundwater has led to rapid declining of groundwater level.

\section{Rain Water Harvesting Structure}

Rain water harvesting structures are used to store the excess rainfall using check dam, Lake Farm pond, bundies and recharge pits and borewells. Coimbatore city has got eight lakes to store the rain water. But this alone is not sufficient. There is a need to store the rain water through recharge structures at various parts of the city to augment the groundwater and take maximum chance of using rain water this structure filters runoff water and recharges the clean water into the ground through a drilled bore well. Due to hard rock strata of Coimbatore region, it is important to construct recharge bore well, recharge pit and filter materials like sand, boulders, blue metals etc. The intake capacity of the bore well depends upon the number of crack zones getting encountered during the vertical drill. Constructing rain water harvesting structure around such bore well pits is an innovative initiative to harness the storm-water marooning on low-lying areas and to recharge the same as groundwater.

\section{Methodology}

Importance of GIS in handling spatial data is elaborated by Elangovan [4]. Following is the flowchart of activity followed in this research work,

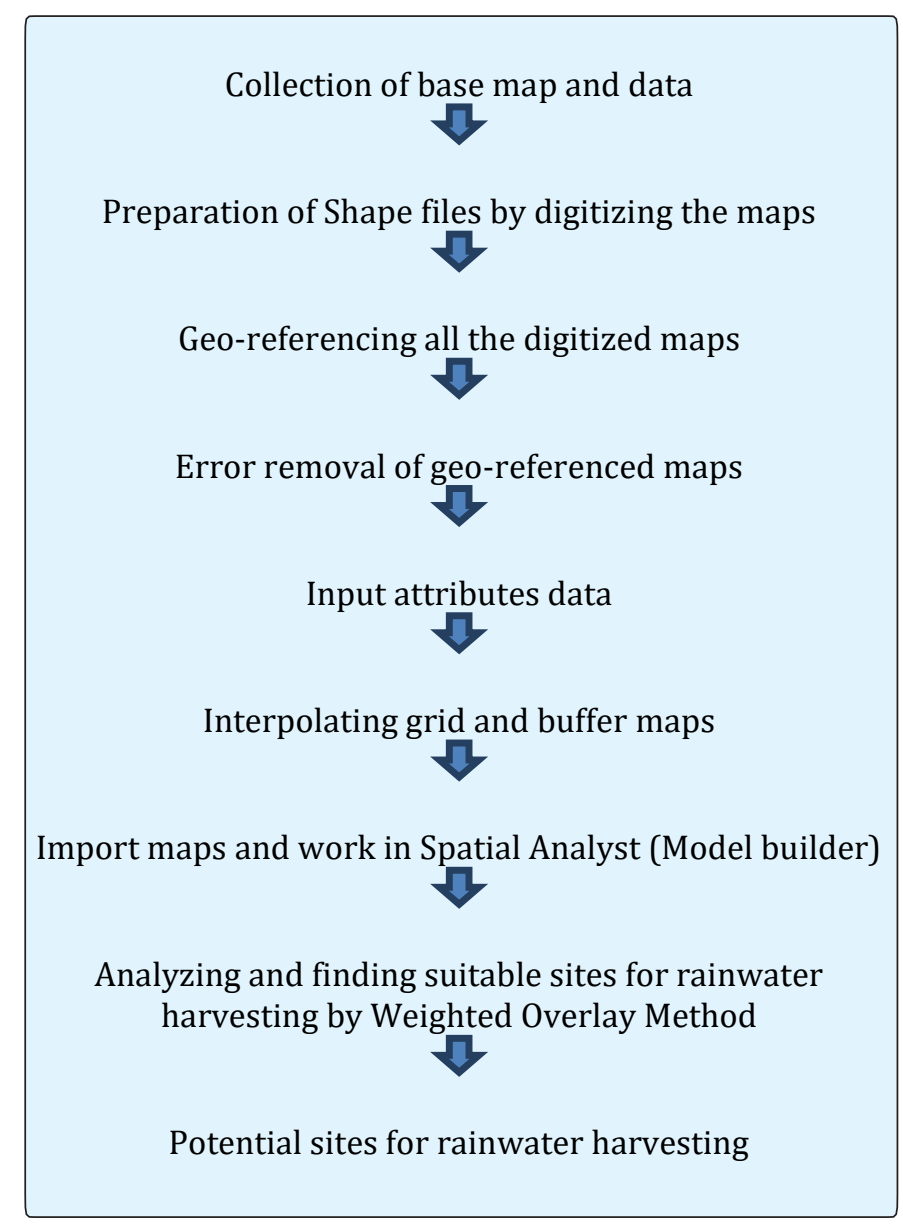

\section{Data Acquisition}

Data for the determination of potential sites for rainwater harvesting.

Lineament: Lineaments are the major fractures store and conduct water beneath the ground. Lineament map ofthe study area has been prepared as it supports higher recharge of groundwater. Figure 1 shows the lineament map of the city. 


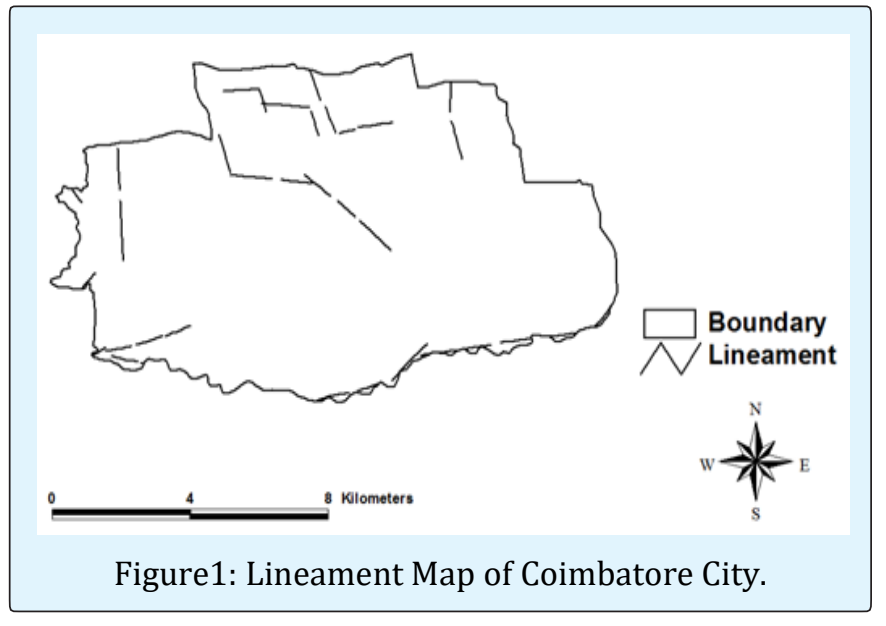

Digital Elevation Model (DEM): Survey of India topographic sheet was obtained in 1:25,000 scales and contour map was prepared for the city. From the contour map, digital elevation model (DEM) was prepared and shown in Figure 2.

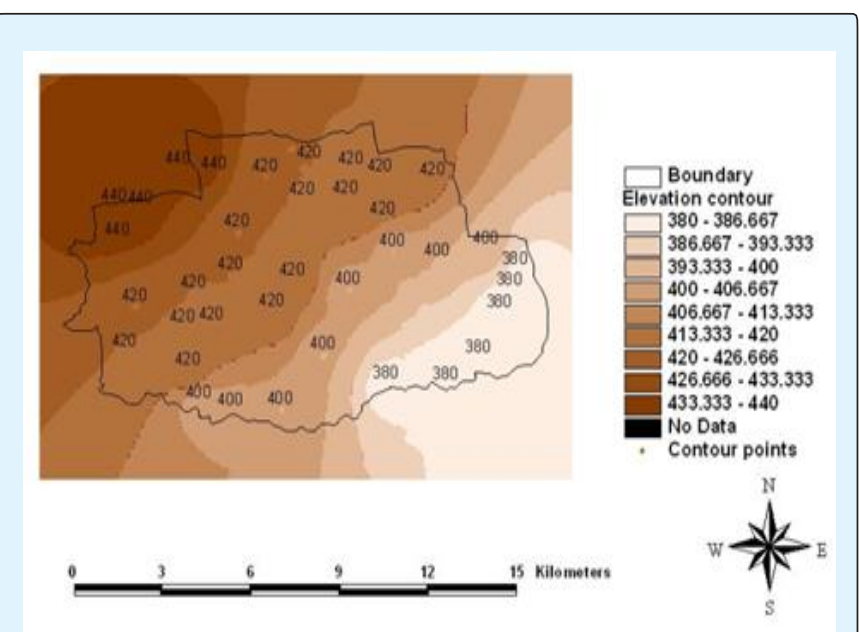

Figure 2: Digital Elevation Map of Coimbatore City.

Subsequently it has been converted into GRID for the necessary raster overlays in the further GIS analysis. The elevation of the study area ranges from $380 \mathrm{~m}$ to $440 \mathrm{~m}$ from the mean sea level.

Geology: Coimbatore district is underlain by a wide range of high grade metamorphic rocks of the peninsular gneissic complex. Coimbatore city composed of gneiss and silt \& clay as major geological formations and shown in Figure 3.

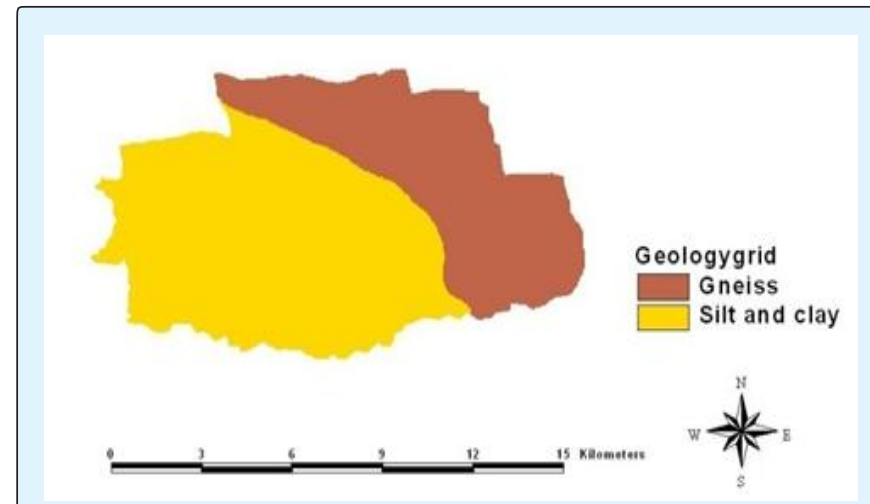

Figure 3: Geology Map of Coimbatore City.

Geomorphology: Geomorphology is concerned with the structure, origin, and development of the topographical features of the earth's surface. Geomorphology maps help to identify the various geomorphic units and groundwater occurrence in each unit. The geomorphic units like deep pediment, moderate pediment, shallow pediment and dissected /undissected plateau were present.

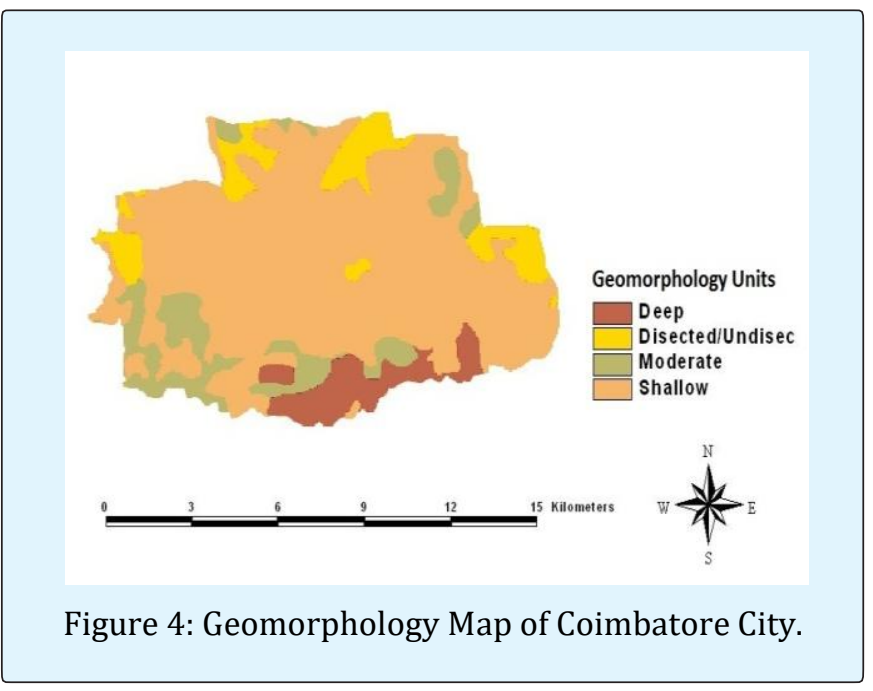

\section{Decision Support System}

Maps like geology, soil, geomorphology, lineament, digital elevation model were brought into model builder in ArcView GIS and weightedoverlay was carried out and shown in Figure 5. Sites with poor, bad, moderate, good and very good zones for erecting rainwater harvesting structures are found. This result may vary if the weightages are given differently or few more maps are considered. 


\section{Journal of Ecology \& Natural Resources}

\section{Results and Discussion}

Based on the bore well samplings tested, preferred soil type is gravel. Since gravel is not available throughout the study area sand, silt and clay where given influence factors accordingly. As a result, low lying areas where selected as the suitable rain water harvesting sites which are also rich in gravel and sand. Effective lineament isbe considered without any objection which also has resulted in the suitable site selection for rain water harvesting.

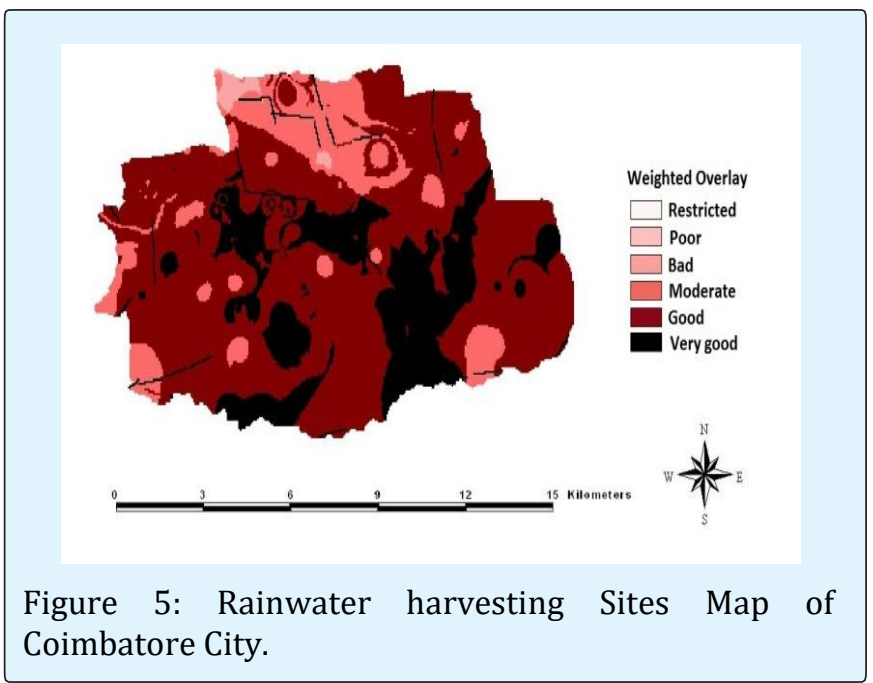

The important areas comes under suitable sites for rainwater harvesting are Singanallur, Kallimadai, Sowripalayam, Masakalipalayam, Karumbukadai, MGR nagar, R.S.puram, Tatabad, TNHB Quraters, Anuparpalayam village, Coimbatore RS, Upilipalayam, Lakshmi mills, Ramakrishnapuram, Gandhi park, Ponnaiyarajapuram, Corporation office, Collector office, Selvampathi tank, SNR college and Avinashilingam home science college.

\section{Conclusion}

The study has provided sites for rain water harvesting for Coimbatore city. Rain water harvesting structures if built can prove to be very effective in saving water for future use. The study has demonstrated the capabilities of using geographic information system for identifying potential sites for rainwater harvesting.

\section{References}

1. Geetha S, Elangovan K (2009) Hydro geochemistry analysis of groundwater in Noyyal river basin. Int J Applied Engineering Research 4(2): 211-227.
2. Arumugam K, Elangovan K (2009) Hydrochemical Characteristics and Groundwater Quality Assessment in Tirupur Region, Coimbatore District, Tamil Nadu, India. Environ Geology 58(7): 509-1520.

3. Arumugam K, Elangovan K (2010) Quality Characterization of Groundwater in Tirupur Region, Tamil Nadu, India, IJAER 5(1): 9-24.

4. DurgaRao KHV, Bhaumik MK (2005) Spatial Expert Support System in Selecting Suitable Sites for Water Harvesting Structures. Geocarto Int 18(4): 43-50.

5. Ghayoumian J, Mohseni MS, Feiznia S, Nouri B, Malekian A (2006) Application of GIS techniques to determine areas most suitable for artificial groundwater recharge', in a coastal aquifer in southern Iran. J Asian Earth Sci 30(2): 364-374.

6. Abdallah BM, Ismail C (2007) The Groundwater recharge study in arid region", Minerals Resources and Environment Laboratory, Department of Geology, Faculty of Sciences of Tunis, El Manar, Tunisia. Computers \& Geosciences 36(6): 801-817.

7. GavadeVV, Patil RR, PalkarJM, Kachare KY (2011) Site suitability analysis for surface rainwater harvesting of Madhatahsil, Solapur, Maharashtra: a geoinformatic approach. $12^{\text {th }}$ Esri India User Conference 4(8): 455-462.

8. GeethaSelvarani A, Maheswaran G, Elangovan K (2014) Evaluation of groundwater potential zones using GIS , and remote sensing in Noyyal Basin, Tamil Nadu, India. Int J Environ Tech Manag 17(5): 377392.

9. Geetha Selvarani A, Maheswaran G, Elangovan K, Siva Kumar C (2015) Identification of artificial recharge sites for noyyal watershed using GIS and fuzzy logic. Int J Applied Engineering Res 10(4): 11189-11208.

10. Samson S, Elangovan K (2015) Delineation of Groundwater Recharge Potential Zones in Namakkal District, Tamilnadu, India Using Remote Sensing and GIS. J Indian Society of Remote Sensing 43(4): 769778.

11. Maheswaran G, GeethaSelvarani A, Elangovan $\mathrm{K}$ (2016) Groundwater resource exploration in salem district, Tamil nadu using GIS and remote sensing. J Earth System Science 125(2): 311-328. 


\section{Journal of Ecology \& Natural Resources}

12. Geetha Selvarani A, Maheswaran G, Elangovan K, (2017) Identification of Artificial Recharge Sites for Noyyal River Basin Using GIS and Remote Sensing. J Indian Society of Remote Sensing 45(1): 67-77.

13. Selvarani AG, Elangovan K, Kumar CS (2016) Evaluation of groundwater potential zones using electrical resistivity and GIS in Noyyal river basin, Tamil Nadu. J Geological Society of India 87(5): 573582.

14. Elangovan K (2006) GIS: Fundamentals, Applications and Implementations, New India Publishing Agency, New Delhi, 208.

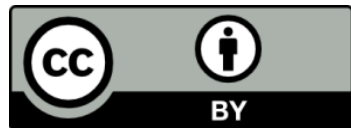

